\title{
A Simultaneous-Equation Model of Estimating the Response of the Consumer Price to Exchange Rate Movements in Thailand
}

\author{
Yu Hsing \\ College of Business, Southeastern Louisiana University, Hammond, LA 70402, USA \\ E-mail: yhsing@ selu.edu
}

Received: February 8, 2020

Accepted: February 26, 2020

Published: February 28, 2020

doi:10.5296/ber.v10i1.16406

URL: https://doi.org/10.5296/ber.v10i1.16406

\begin{abstract}
This paper examines exchange rate pass-through (ERPT) to the consumer price in Thailand based on a simultaneous-equation model consisting of the IS, LM and AS function. It employs comparative static analysis to determine the impact of a change in an exogenous variable on the equilibrium price level. The paper finds that a $1 \%$ depreciation of the Thai baht tends to cause the CPI to rise by $0.0696 \%$ and has declined since the adoption of inflation targeting in 2000. In addition, more money supply, more government deficit as a percent of GDP, a higher crude oil price, a higher U.S. CPI, and a higher expected price tends to raise Thailand's CPI. The findings suggest that in addition to the exchange rate, other relevant variables such as fiscal policy, monetary policy, the crude oil price, U.S. price level and the expected price level are expected to impact the consumer price level.
\end{abstract}

Keywords: Exchange rate pass-through, Exchange rates, Consumer prices, Money supply, Crude oil prices

\section{Introduction}

Consumer prices in Thailand have continued to rise with the exceptions in 2009 and 2015. Percent change in consumer prices was higher than 5.0\% during 1994-1998. The inflation rate of $7.94 \%$ in 1998 was mainly caused by the substantial depreciation of the Thai baht during the Asian financial crisis. Since 2014, the percent change in consumer prices was less than $2.0 \%$, suggesting that monetary policy by adopting inflation targeting has been relatively successful in recent years.

Exchange rate pass-through (ERPT) to domestic prices has been a concerned subject for Thailand as it was the origin of the Asian financial crisis in the 1990s. In the 1990s, the 
exchange rate measured as units of the Thai baht per U.S. dollar changed from 24.9152 in 1995 to 41.3594 in 1998, indicating that the value of the Thai baht declined $66.00 \%$ versus the U.S. dollar during this time period. The consumer price index rose $20.69 \%$ during the same period, suggesting that percent change in consumer prices was much less than percent change in the exchange rate. During the global financial crisis, the exchange rate was pretty stable and changed from 34.5182 in 2007 to 34.2853 in 2009. Recently, the Thai baht depreciated 5.9\% from 30.4917 in 2011 to 32.3102 in 2018. Large depreciation of the Thai baht is expected to raise consumer and other prices through the distribution chain. It is an empirical question as to how the consumer price would react to the depreciation of the Thai baht.

To the author's knowledge, few of previous studies have applied and extended IS-LM-AS model in studying ERPT to consumer prices in Thailand. This paper has several different aspects. First, the paper uses an extended IS-LM-AS model incorporating the exchange rate in the money demand function. Second, in the aggregate supply function, external shocks represented by the exchange rate and the energy cost are considered. Third, comparative static analysis is employed to determine how exchange rate movements would affect the equilibrium price level.

\section{Literature Survey}

Several recent studies have examined ERPT to prices for Thailand and related countries. Pholphirul (2003) investigated ERPT to import prices for nine sectors in Thailand during 1996.M1 - 2003.M5. ERPT declines after the Asian financial crisis. Long-run ERPT is greater than short-run ERPT. After the Asian financial crisis, ERPT to import prices ranges from a low of 0.120 for crude materials to 0.475 for miscellaneous goods in the short run and ranges from 0.745 for crude materials to 1.456 for machinery in the long run. Six sectors have ERPT to import prices close to or greater than one.

Applying the SVAR model to selected East Asian and Latin American countries and Turkey, Ito and Sato (2007) examined ERPT to prices after the Asian financial crisis. They found that ERPT is stronger in Turkey and the Latin American countries than in East Asian countries except for Indonesia. Credible monetary policy would reduce ERPT to prices. Transmission from the import or producer price to the consumer price is pretty large in Indonesia, Mexico and Turkey. For Thailand, ERPT to the consumer price is found to be 0.01 in the first month and 0.05 in 12 months, suggesting that ERPT to the CPI is relatively small and incomplete.

Ito and Sato (2008) applied the VAR model to estimate ERPT for five selected Asian countries including Thailand after the Asian financial crisis. ERPT declines along the distribution chain from import prices to producer prices and to consumer prices. ERPT to the import price was relatively high whereas ERPT to the CPI was relatively low except for Indonesia.

Using the VAR technique, Kohlscheen (2010) examined ERPT to consumer prices for eight countries including Thailand with floating exchange rate systems. He found that ERPT is greater for countries trading more homogeneous goods and with higher exchange rate 
volatility. ERPT after one year ranges from a low of 0.09 for the Philippines to a high of 0.60 for Indonesia. For Thailand, it is estimated to be 0.16 .

Prasertnukul, kim and Kakinaka (2010) investigated the effect of inflation targeting on ERPT for several selected Asian countries including Thailand. For Thailand, ERPT to the CPI is found to be 0.124 in the long run and remains unchanged before and after adopting inflation targeting. For South Korea, ERPT to the CPI declines from 0.150 before adopting inflation targeting to 0.076 after adopting inflation targeting in the long run.

Saha and Zhang (2013) evaluated ERPT for Australia, China and India using the VAR model during 1990-2011. They found that ERPT to consumer prices is less in China and India than in Australia, that the depreciation of the yuan and rupee causes domestic price inflation, and that external variables have little impact on domestic prices in China and India, but interest rates, producer prices and industrial production effect their domestic prices.

Using the VARX model for six emerging countries including Thailand, Aleem and Lahiani (2014) studied ERPT to domestic prices. ERPT tends to be lower in countries with a more credible monetary policy, in Asian countries than in Latin American countries, and after the adoption of inflation targeting. For Thailand, ERPT is estimated to be 0.14 before the adoption of inflation targeting and 0.02 after the adoption of inflation targeting.

Based on a sample of nineteen high and middle countries including Thailand, Dilla, Achsani and Anggraeni (2017) examined whether the adoption of inflation targeting (IT) would affect ERPT to the consumer price. The results are mixed. For Thailand, before the adoption of IT, ERPT to consumer prices is estimated to be 0.037 in the long run; and after the adoption of IT, ERPT to consumer prices is found to be 0.004 in the long run. Hence, after the adoption of IT, ERPT to prices declines in the long run.

Using a sample of 15 emerging economies including Thailand during 1994-2015, López-Villavicencio and Mignon (2017) assessed the impacts of inflation, inflation targeting and transparency of monetary policy on ERPT to prices. According to the findings, a less volatile and a more anti-inflationary environment reduce ERPT; the adoption of inflation targeting results in a substantial decrease in ERPT; and more transparency of monetary policy also leads to a declining ERPT.

Applying the nonlinear ADRL technique, Termprasertsakul (2018) evaluated ERPT to the CPI and PPI for Thailand during 2007.M1 - 2017.M12. There is no ERPT to the CPI and PPI in the long run, but there is partial ERPT in the short run. It is also confirmed that there exists asymmetric pass-through in the short run. The appreciation of the Thai baht has a stronger pass-through than the depreciation of Thai baht.

Applying the SVAR model, Anh, Quan, Phuc, Chi and Duc (2018) examined ERPT to the CPI and PPI for five ASEAN countries including Thailand. For Thailand, ERPT to the CPI is 0.03 in the first quarter and declines to zero in the 8th quarters, and ERPT to the PPI is 0.17 in the first quarter and 0.13 in the $8^{\text {th }}$ quarter, suggesting that ERPT to the PPI is stronger than the CPI. Variance in the CPI is mainly caused by shocks to the oil price, the lagged CPI, the lagged PPI. Shocks to the interest rate and exchange rate play minor roles. 
Assessing ERPT in six selected Asian countries including Thailand during 1980.Q1 to 2014.Q3, Soon, Baharumshah, and Wohar (2018) found evidence of ERPT to the consumer price if inflation volatility is greater than 4.1725. The extent of ERPT differs owing to low and high inflation volatility in non-inflation and inflation targeting countries.

Based on a sample of forty-seven countries including Thailand, Ha, Stocker and Yilmazkuday (2019) showed that ERPT to inflation varies among countries over time depending on the factors causing exchange rate changes and country characters. Countries pursuing credible inflation targets and flexible exchange rate systems tend to have smaller pass-through ratios. More central bank independence helps to stabilize inflation and make the exchange rate as a cushion against external shocks.

Examining ERPT for selected Asian countries including Thailand during 1995.Q1-2016.Q4 and employing the nonlinear ARDL method, Kassi, Sun, Ding, Rathnayake and Assamoi (2019) showed that there is an asymmetric ERPT to prices in Asian developing countries in the short run and in Asian emerging countries in the short and long run, that ERPT is higher for the appreciation than the depreciation in the long run, and that there is evidence of downward rigid price and weak competition. They also showed that ERPT has not declined in these Asian countries in the long run. If a currency appreciates (depreciates) $1 \%$, the consumer price would decline $0.9 \%$ (rise $0.5 \%$ ) in the long run. ERPT is higher in emerging Asian countries with lower inflation and price volatility than in developing Asian countries.

\section{The Model}

It is postulated that aggregate spending is determined by real income, government tax revenue, government spending, the real interest rate and the real exchange rate, that real money demand is a function of the nominal interest rate, real income and the nominal exchange rate, and that the price level is represented by an augmented expectations supply function where the price level is influenced by the expected price level, the output gap, the nominal exchange rate, and the energy cost. Extending the IS-LM-AS model (Romer, 2006), we have:

$$
\begin{gathered}
Y=w\left[Y, T, G, R-\pi^{e}, \varepsilon\left(P^{*} / P\right)\right] \\
M / P=x(R, Y, \varepsilon) \\
P=z\left(P^{e}, Y-Y^{*}, \varepsilon, E\right)
\end{gathered}
$$

where

$\mathrm{Y}=$ real GDP in Thailand,

$\mathrm{T}$ = government taxes,

$\mathrm{G}$ = government spending,

$\mathrm{R}=$ the nominal interest rate, 
$\pi^{e}=$ the expected inflation rate,

$\varepsilon=$ the nominal exchange rate measured as units of the Thai baht per U.S. dollar,

$\mathrm{P}^{*}=$ the price level in the U.S.,

$\mathrm{P}=$ the price level in Thailand,

$\mathrm{M}=$ the money supply,

$\mathrm{P}^{\mathrm{e}}=$ the expected price level,

$\mathrm{Y}^{*}=$ potential real GDP, and

$\mathrm{E}=$ the energy cost.

Assume that potential real GDP is a constant in the short run. Solving for the endogenous variables (Y, $\mathrm{R}-\pi^{e}$, and $\mathrm{P}$ ) simultaneously, we can obtain the equilibrium price level as:

$$
\bar{P}=\bar{P}\left(\varepsilon, M, G-T, E, P^{*}, P^{e}\right)
$$

Equation (4) suggests that in the reduced form equation, the equilibrium price level is affected by the nominal exchange rate, the money supply, government deficit, the energy cost, the U.S. price level, and the expected price level. It should be noted that right-hand side variables may be corrected. For instance, monetary or fiscal expansion is expected to affect the exchange rate under a floating exchange rate regime in the Mundell-Fleming model. Using log-transformed data would reduce a high degree of correlation among exogenous variables.

The determinant of the Jacobian matrix is given by:

$$
|J|=\left[-\left(1-w_{Y}\right) x_{R}-w_{R} z_{Y} M P^{-2}+w_{P} x_{R} z_{Y}-w_{R} x_{Y}\right]>0
$$

The partial derivative of $\bar{P}$ with respect to $\varepsilon$ can be expressed as:

$$
\begin{gathered}
\partial \bar{P} / \partial \varepsilon=\left[-x_{R} z_{\varepsilon}\left(1-w_{Y}\right)-\right. \\
\left.w_{\varepsilon} x_{R} z_{Y}-w_{R} x_{Y} z_{\varepsilon}+w_{R} x_{\varepsilon} z_{Y}\right] /|J|>0 \text { if } x_{\varepsilon}<0 \\
<\text { or }>0 \text { if } x_{\varepsilon}>0 .
\end{gathered}
$$

In equation (6), the sign of the first three terms in the numerator is positive whereas the sign of the last term in the numerator depends on the sign of $x_{\varepsilon}$. The exchange rate may affect real money demand via the wealth effect and the substitution effect (Arango and Nadiri, 1981). If the substitution effect dominates the wealth effect, the sign in equation (6) would be positive. On the other hand, if the wealth effect dominates the substitution effect, the sign in equation (6) would be unclear.

The sign of the money supply, government deficit, the energy cost, the U.S. price and the expected price should be positive. More money supply or government deficit tend to shift aggregate demand to the right and raise the price level. A higher energy cost, U.S. price or expected price level tends to shift short-run aggregate supply to the left and raise the price level. 


\section{Empirical Results}

The data were collected from the International Financial Statistic and the World Economic Outlook published by the International Monetary Fund. The price level is represented by the consumer price index. The nominal exchange rate is measured as units of the Thai baht per U.S. dollar. The money supply is represented by broad money measured in millions. $G-T$ is expressed as the government deficit as a percent of GDP. The crude oil price per barrel is selected to represent the energy cost. The U.S. consumer price index is chosen to represent the U.S. price. The expected consumer price index is estimated as a weighted average consumer price index of the past four years.

The EGARCH process is employed in empirical estimation in order to correct for potential autoregressive conditional heteroskedasticity. The advantage of the EGARCH process is that it does not have the restriction of positive values for the parameters in the conditional variance equation. The estimated coefficients in the conditional variance equation are significant at the $1 \%$ level, suggesting that the use of the EGARCH process is justified. An alternative is the SVAR model, which assumes that error terms are uncorrelated and that variables can have a simultaneous effect on other variables. The SVAR is normally employed for low-frequency data whereas this paper uses annual data. Hence, the SVAR may be applied when a low-frequency data is used.

Table 1 presents the estimated regression and related statistics. The six independent variables can explain approximately $99.17 \%$ of the variation in the consumer price index. All the estimated coefficients are statistically significant at the $1 \%$ level. The CPI in Thailand has a positive relationship with the nominal exchange rate, broad money, the government deficit-to-GDP ratio, the crude oil price, the U.S. price level, and the expected price level.

Table 1. Estimated Regression of the $\log (\mathrm{CPI})$ in Thailand

\begin{tabular}{|l|l|l|}
\hline Variable & Coefficient & Probability \\
\hline Intercept & 1.0709 & 0.0000 \\
\hline Log(exchange rate) & 0.0696 & 0.0000 \\
\hline Log(broad money) & 0.2441 & 0.0000 \\
\hline Government deficit/GDP ratio & 0.0039 & 0.0106 \\
\hline Log(crude oil price) & 0.0653 & 0.0000 \\
\hline Log(U.S. consumer price index) & 0.1416 & 0.0000 \\
\hline Log(expected CPI) & 0.0130 & 0.0004 \\
\hline R-squared & 0.9917 & \\
\hline Adjusted R-squared & 0.9979 & \\
\hline Akaike information criterion & -5.6852 & \\
\hline Schwarz criterion & -5.1892 & \\
\hline Sample period & $1997-2018$ & \\
\hline Number of observations & 22 & \\
\hline
\end{tabular}

Notes: The CPI is the consumer price index.

The exchange rate is measured as units of the Thai baht per U.S. dollar. 
Specifically, if the exchange rate rises $1 \%$, the CPI will increase by $0.0696 \%$. If broad money rises $1 \%$, Thailand's CPI will increase by $0.2441 \%$. A 1 percentage point increase in the government deficit-to-GDP ratio will cause the $\log$ of the CPI to rise by 0.0039 . A $1 \%$ increase in the crude oil price will raise the CPI by $0.0653 \%$. When U.S. CPI rises $1 \%$, Thailand's CPI will increase by $0.1416 \%$. If the expected consumer price index rises $1 \%$, Thailand's CPI will increase by $0.0130 \%$.

Several possible reasons may explain relatively small exchange rate pass-through to consumer prices. The depreciation of the Thai baht tends to shift aggregate demand to the right and aggregate supply to the left. On the other hand, the depreciation tends to cause international capital outflows, reduce spending on investment, real estate and other related goods and services, and shift aggregate demand to the left. The second effect may partially cancel out the degree of ERPT to consumer prices. Exporters selling products to Thailand may absorb part of the price increase in order to maintain the market share. Retailers may absorb part of the pric increase in order to prevent sales from declining. Consumer spending on imports may constitute a small proportion out of total spending.

If a linear form is estimated, similar results are obtained. The estimated coefficient becomes the slope. The value of R-squared is estimated to be $99.34 \%$. All the estimated coefficients are positive and significant at the $1 \%$ level. As exchange rate pass-through measures percent change in the price level over percent change in the exchange rate, the log-log form would be a better choice.

To determine whether ERPT to the CPI may have declined since the adoption of inflation targeting in 2000, an intercept binary variable and an interactive binary variable of the exchange rate are included in the estimated regression (Edwards, 2006). The result shows that the coefficient of the interactive dummy variable of the exchange rate is negative and significant at the 1\% level. Hence, ERPT to the CPI has declined in Thailand since 2000.

In comparison, the estimated ERPT to the consumer price in this paper is greater than the estimates found by Ito and Sato (2007) and Anh, Quan, Phuc, Chi and Duc (2018) and less than the estimates reported by Ito and Sato (2008), Prasertnukul, Kim and Kakinaka (2010) and Kohlscheen (2010). The finding that ERPT to the consumer price declines after the adoption of inflation targeting is consistent with the results reported by Aleem and Lahiani (2014) and Dilla, Achsani and Anggraeni (2017) but in contrast with the finding presented by Prasertnukul, Kim and Kakinaka (2010).

\section{Summary and Conclusions}

This paper has examined ERPT to consumer prices in Thailand based on an extended IS-LM-AS model. In the simultaneous-equation model, the equilibrium consumer price index is determined by the nominal exchange rate, broad money, the government deficit as a percent of GDP, the crude oil price, the U.S. consumer price index, and the expected consumer price index. The depreciation of the Thai baht, more broad money, more government deficit as a percent of GDP, a higher crude oil price, a higher U.S. consumer price index, and a higher expected consumer price index tend to cause Thailand's consumer 
price to rise. Exchange rate pass-through to consumer prices in Thailand is relatively small and has declined since the adoption of inflation targeting in 2000.

There are several policy implications. First, the Thai baht exchange rate versus the U.S. dollar changed from a high of 44.4319 in 2001 to a low of 30.4917 in 2011 and 32.3102 in 2018. These statistics suggest that the Thai baht appreciated 31.31\% during 2001-2011, depreciated $5.90 \%$ during 2011-2018, and appreciated 28.25\% during 2001-2018. The depreciation of $5.90 \%$ during 2011-2018 may raise the concern of ERPT to consumer prices whereas the appreciation during 2001-2018 is expected to mitigate the concern about exchange rate pass-through to consumer prices. Second, the consumer price index is also affected by the money supply. Hence, the authorities may need to make sure that the growth rate of the money supply is consistent with the growth rate of real GDP in order to avoid high inflation. An analysis of the data shows that the growth rate of broad money was near or below 5\% after 2013 and that the growth rate of real GDP was between $2.04 \%$ and $4.12 \%$ after 2013 . Thus, percent change in the price level would be moderate. The adoption of inflation targeting in 2000 seems to have reduced inflation rates in recent years. Third, external shocks such as crude oil prices and the U.S. consumer prices tend to affect Thailand's domestic prices. The government may need to monitor changes in these prices in order to measure their impacts on Thailand's domestic price level.

\section{Conflict of interest}

The authors declare no potential conflict of interest.

\section{References}

Aleem, A., \& Lahiani, A. (2014). Monetary policy credibility and exchange rate pass-through: Some evidence from emerging countries. Economic Modelling, 43, 21-29. https://doi.org/10.1016/j.econmod.2014.06.020

Anh, V. T., Quan, L. T. T., Phuc, N. V., Chi, H. M., \& Duc, V. H. (2018). Exchange rate pass-through in ASEAN countries: an application of the SVAR model. Emerging Markets Finance and Trade, 1-14. https://doi.org/10.1080/1540496X.2018.1474737

Arango, S., \& Nadiri, M. I. (1981). Demand for money in open economies. Journal of Monetary Economics, 7(1), 69-83. https://doi.org/10.1016/0304-3932(81)90052-0

Dilla, S., Achsani, N. A., \& Anggraeni, L. (2017). Do inflation targeting really reduced exchange rate pass-through?. International Journal of Economics and Financial Issues, 7(3), 444-452.

Edwards, S. (2006). The relationship between exchange rates and inflation targeting revisited (No. w12163). National Bureau of Economic Research. https://doi.org/10.3386/w12163

Ha, J., Stocker, M., \& Yilmazkuday, H. (2019). Inflation and exchange rate pass-through. The World Bank. https://doi.org/10.1596/1813-9450-8780

Ito, T., \& Sato, K. (2007). Exchange rate pass-through and domestic inflation: A comparison between East Asia and Latin American countries. Research institute of Economy, Trade and 
Industry, RIETI Discussion Papers, 7040.

Ito, T., \& Sato, K. (2008). Exchange rate changes and inflation in post-crisis Asian Economies: Vector autoregression analysis of the exchange rate pass-through. Journal of Money, Credit and Banking, 40(7), 1407-1438.

https://doi.org/10.1111/j.1538-4616.2008.00165.x

Karim, B. (2005). Exchange rate pass-through into import prices in developing countries: An empirical investigation. Economics Bulletin, 3(26), 1-14.

Kassi, D. F., Sun, G., Ding, N., Rathnayake, D. N., \& Assamoi, G. R. (2019). Asymmetry in exchange rate pass-through to consumer prices: Evidence from emerging and developing Asian countries. Economic Analysis and Policy, 62, 357-372.

https://doi.org/10.1016/j.eap.2018.09.013

Kohlscheen, E. (2010). Emerging floaters: Pass-throughs and (Some) New commodity currencies. Journal of International Money and Finance, 29, 1580-1595.

https://doi.org/10.1016/j.jimonfin.2010.05.013

López-Villavicencio, A., \& Mignon, V. (2017). Exchange rate pass-through in emerging countries: Do the inflation environment, monetary policy regime and central bank behavior matter?. Journal of International Money and Finance, 79, 20-38.

https://doi.org/10.1016/j.jimonfin.2017.09.004

Pholphirul, P. (2003). Exchange rate pass-through in Thailand's import industries. TDRI Quarterly Review, 18(4), 15-19.

Prasertnukul, W., Kim, D., \& Kakinaka, M. (2010). Exchange rates, price levels, and inflation targeting: Evidence from Asian Countries. Japan and the World Economy, 22(3), 173-182. https://doi.org/10.1016/j.japwor.2010.03.002

Romer, D. (2006). Advanced Macroeconomics, 3rd edition. Boston: McGraw-Hill/Irwin.

Saha, S., \& Zhang, Z. (2013). Do exchange rates affect consumer prices? A comparative analysis for Australia, China and India. Mathematics and Computers in Simulation, 93, 128-138. https://doi.org/10.1016/j.matcom.2012.11.002

Soon, S. V., Baharumshah, A. Z., \& Wohar, M. E. (2018). Exchange rate pass-through in the Asian countries: does inflation volatility matter?. Applied Economics Letters, 25(5), 309-312. https://doi.org/10.1080/13504851.2017.1319553

Termprasertsakul, S. (2018). Exchange rate pass-through to domestic price indices in Thailand. Economics and Public Policy Journal, 9(17), 59-74.

Tunç, C. (2017). A survey on exchange rate pass through in emerging markets. Bulletin of Economic Theory and Analysis, 2(3), 205-233. https://doi.org/10.25229/beta.334253

Wattanakoon, P. (2013). Exchange rate pass-through and inflation in Thailand. Thailand and The World Economy, 31(2), 64-80. 


\section{Macrothink}

Business and Economic Research

ISSN 2162-4860 2020, Vol. 10, No. 1

Yilmazkuday, H. (2013). Inflation targeting, flexible exchange rates and inflation convergence. Applied Economics, 45(5), 593-603.

https://doi.org/10.1080/00036846.2011.608642

Yilmazkuday, H. (2015). Pass-through of trade costs to US import prices. Review of World Economics, 151(4), 609-633. https://doi.org/10.1007/s10290-015-0218-9

\section{Copyright Disclaimer}

Copyright for this article is retained by the author(s), with first publication rights granted to the journal.

This is an open-access article distributed under the terms and conditions of the Creative Commons Attribution license (http://creativecommons.org/licenses/by/3.0/). 